\section{ON THE ETIOLOGY OF SCURVY. ${ }^{1}$}

By MYer COplans, M.B. LoN1), D.P.H. Camb., LATE CIVIL SURGEON ATTACHED TO THE ROYAL ARMY MEDICAT, CORPS, SOU'TI AFRICA.

As I have not dealt at all fully with the clinical aspect of the cases referred to in this paper I may perhaps state here that they conformed in every particular to what, I take it, would be regarded as typical scurvy. As to this no question has been raised, but I make the statement with the view of clearing up any doubts which may arise on this point. Briefly the subjects of these cases presented during life spongy bleeding gums, lassitude, anæmia, and breathlessness on exertion, followed later by lameness associated with synovitis in the joints, and hæmorrhages with brawny indurated swellings in one or both of the lower limbs. The urine was slightly acid. The blood showed marked poikilocytosis in the red discs. There were no nervous lesions. Death took place from cardiac failure usually and post mortem the blood was flaid ; there were subserous, submucous, subpleural petechiæ. The heart was thin and pale, the right side being dilated, and there was excess of serous fluid in the pericardium. The body was well nourished.

Farther, I wish to explain my attitude in the matter. I bave approached the subject with a perfectly open mind and before this Transvaal experience I had no special acquaintance with scurvy. After studying this outbreak I endeavoured to explain it by the current views as to the causation of the disease but failed. I am therefore venturing to submit this thesis to the judgment of the society. I would ask you to approach the subject $d e$ novo, with open minds, setting aside for the present all historical writings and sayings on the matter, treating this oatbreak of the disease as an entity, and in particular bearing in mind the fact that the question of the antiscorbutic value of any food is not being raised. I propose to lay before you some evidence pointing to the fact that the condition known as scurvy in adults is not brought about by the absence of any particular kind of food from the dietary but is more probably a specific infection of bacterial origin.

Towards the close of the Boer war, in May, 1902, there was presented the unusual spectacle in the Transvaal and Orange River colonies of lands devastated by fire, devoid of farms, of crops, and of cattle, with the entire human population-natives and Europeans, combatants and non-combatants-gathered together into a series of small communities or units, of fixed location and definite occupation, under supreme military control. Each of these units was supplied by the military authorities with food, this food being mainly imported from over sea and transported up country along closely guarded railway tracks. Thus every individual in every community was definitely rationed. Except in the few towns that still remained undestroyed it was found impossible to obtain food of any description save that imported. For the inhabitants remaining in these undestroyed towns there were provision stores which supplied goods at fixed prices and in definite quantities only, The shops, the inhabitants, and their houses were under close military supervision by day and night. Solely for the use of the military classes there were instituted the field-force canteens which supplied additional articles of fond on payment. These canteens, though private ventures, were also under military control, and the demand from them by the troops for goods was nearly always in excess of their power to supply. The goods sold at these canteens were principally imported preserved foods and thus all in British military employ were enabled in some measure to supplement their regular rations. All other classes were dependent entirely on the Government for rations ; and about this period every individual in the country could, with some degree of certainty, be accounted for officially as to dwelling place, employment, and amount and nature of food consumed. From the military organisation of affairs and division of the inbabitants into units no individual non-combatant could fare better or worse in his food-supply than the remaining members of his own unit. Thus all burgher camp inhabitants participated equally in the general food supply for the bargher camp population and so with the

1 A paper read before the Epidemiological Society of London on Feb. 19th, 1904. natives attached to the British army and the regular European troops. For each of them as a class there was a definite food-supply per individual, based on the general stores of food in the country and issued under the control of the military anthorities. Sometimes the burgher camp population fared better than the troops; at other times the positions were reversed.

The evidence supporting the contention that scurvy is caused by a specific infection is derived from two sourcesviz., the study of the epidemic behaviour of the disease and the study of its clinical features. The incidence of scurvy in the Fastern Transvaal will be considered in the following units : (1) the burgher concentration camps; (2) the Kuropean soldiers; (3) African natives attached to the British army; and (4) African natives attached to the civilian Repatriation Department.

1. The burgher concentration camps.-The burgher camps under special observation were those situated at Middelberg, Standerton, and Volkrust. Each camp numbered about 5000 inhabitants, of whom 48 per cent. were children under 12 years of age. The remainder were classed as adults, male and female, and were in the proportion of 1 to 3 The inhabitants lived in tents which were regularly arranged at wide intervals on sloping, well-drained soil, and each camp possessed its own internal medical and educa. tional organisations. Every camp was surrounded by barbedwire fencing and was closely guarded, and as ingress and egress were privileges subject to military control each camp was in a sense an open prison. No food could reach the camps or be distributed to the inhabitants except with official sanction. A definite scale of food, varying with the age of the individual, was laid down and rigorously adhered to. In each camp were separate quarters for the native camp inhabitants. These natives, who likewise had fixed rations, acted chiefly as servants to the members of the camp staffis and to the Datch inhabitants. They averaged 150 per 5000 whites.

The incidence of scurvy at the burgher camps, considered in detail, was as follows. In the camp at Standerton, between March, 1901, and January, 1903, there were no cases of scarvy. In the camp at Volkrust, similar in every respect to that at Standerton and over a similar period, there were no cases of scurvy. In the camp at Middelberg, which was slightly larger than that at Standerton, there were 100 cases among Europeans and one case among natives over a similar period. This outbreak of scurvy among adults at Middelberg, which occurred during December, 1901, and January, 1902 , under a dietary similar in all respects to that in use at the camps at Standerton and Volkrust, immediately lends colour to the suggestion that the cause of scurvy is to be found in conditions other than those usually associated with food. The inhabitants of these camps had no occupation other than their domestic duties.

2. The European soldiers.-The district under inspection as to the prevalence of scurvy among Europeans in British military employ was that of Standerton. All the sick within a radius of 40 miles were received into No. 17 General Hospital, This hospital had advanced up country through Natal with General Buller's army, being known as No. 4 Stationary Hospital, and finally found a resting place at Standerton as No. 17 General Hospital. It comprised 600 beds for Europeans and a variable numberfrom 30 to 70 -for natives in military employ. Between December, 1899, and January, 1903, 22,000 European patients were admitted. This number included 100 sick Boer prisoners of war, 40 sailors of the Royal Navy, and 160 civilians in Government employment. There was not a single case of scurvy among these admissions. Between March, 1902, and February, 1903, 3000 soldiers around Standerton were examined while at their duties and only one was found to be affected with scurvy. This was a private on detached daty, living with, and having charge of, the transport section of the Native Sanitary Corps, and to his case further reference will be made subsequently. Scurvy, therefore, with this single exception was nonexistent among European troops and Europeans in military employ in and around Standerton.

3. African natives attached to the British Army.-With regard to the natives in military employ in and around Standerton the evidence is derived from two sources: the statistics of the native Military Hospital attached to No. 17 General Hospital and a repeated examination of the natives in military employ in the Standerton district. Examination of the hospital record of admissions of natives shows that 
the first case of scurvy admitted occurred in November, 1901. This was the first out of a total of 300 admissions for all causes. Among these 300, however, were 18 cases admitted for indefinite symptoms, such as debility, rhenmatism, inflamed connective tissue, and periostitis. These may possibly have been cases of scurvy. No further cases of scurvy were admitted between November, 1901, and April, 1902. In May, the last month of the war, eight cases of scurvy were admitted, six from the Army Service Oorps Transport Section on May 1st and two from the Sick Horse and Remount Depôts a few days later. In addition there were 27 cases, diagnosable by their symptoms only, of the character above mentioned. The total admissions to hospital from all causes between November, 1901, and May 31st, 1902, were 390. Definite scurvy, therefore, formed 2 per cent. of the total admissions and doubtful scurvy 7 per cent. Between June 1st and Sept. 30th, 1902, there were 193 admissions, including 22 cases of definite scurvy and 20 doubtfal cases, i.e., 11 per cent. and 10 per cent. respectively of total admissions. The last period noted is from October, 1902, to February, 1903. The total admissions numbered 86 . Of these, scurvy accounted for 27 , and there was one doubtful case. Definite scurvy, therefore, formed $28 \frac{1}{2}$ per cent. of all cases admitted during this period.

The following is a summary of the foregoing facts. Between January, 1901, and February, 1903, 970 natives were admitted to the Military Hospital. Before May, 1902, definite scurvy was practically absent. During this month, after a total admission of 600 patients, eight definite cases of the disease occurred and were admitted to hospital. From this month onward nutil Feb. 7th, 1903, the prevalence of scurvy among the hospital admissions gradually increased from 2 per cent. to $28 \frac{1}{2}$ per cent. At the same time the total admissions for dysentery, diarrhœa, and enteric fever fell considerably and the monthly admissions fell from an average of 57 to 21 . It is to be remarked that this notable increase in the percentage of admissions of scurvy cases occurred on the cassation of hostilities when the natives and troops to whom they were attached became stationary and concentrated in fixed camps in and around Standerton. It is of further importance to note that during the latter portion of the period under consideration when scurvy was most prevalent all restrictions in food had been withdrawn, and also all cases admitted came from units stationed in Standerton town.

Such is the information gleaned from the hospital statistics. The increasing proportion of scurvy cases admitted to the native military hospital led to a general inspection of all natives in military employ in and around Standerton. The men were examined in their own quarters while on duty. Outside Standerton, botween March and July, 1902, before the troops and attached natives were concentrated in the towns, no signs of scurvy were found. After the concentration in Standerton natives were again examined and the following results obtained. Those inspected were of two classes, the labourers and the mule-drivers. The labourers were divided into the Native Labour Corps and the Native Sanitary Corps. In the Native Labour Corps there were 117 men employed and 16 per cent. were affected. the Native Sanitary Oorps 37 men were employed and 76 per cent. were affected. The mule-drivers were all attached nominally to regular regiments or corps. The following is a brief statement of the incidence of scurvy among them. Attached to pom-pom section, ten men; none affected. Attached to mounted troops, 67 men; 22 per cent. affected. Attached to Army Service Corps, Transport Section, 400 men; 32 per cent. affected. Detachment in charge of officers' carts, Army Service Corps, nine men; none affected. Detachment employed as police in Army Service Corps camp, eight men; four affected. To return to a consideration of the Native Labour Corps and the Native Sanitary Corps, these two units received exactly the same rations, which consisted of mealie meal $2 \frac{1}{4}$ pounds daily and meat 1 pound weekly. The Native Labour Corps had 16 per cent. affected ; their work was that of heavy goods porterage at the railway station. On the other hand, the Native Sanitary Corps had 76 per cent. affected and their work was that of gathering together the carcasses of animals that had died during the war around Standerton and burying them in pits. The eight men who were occupied in transporting the carcasses by mule wagons to the burial pits were every one of them affected with scurvy, as was also the European soldier in charge of this transport party.
This is the case referred to previously as the only European found affected with scurvy at Standerton. His food was the same as that of the other soldiers at Standerton and was totally different from the food of the natives of the Native Sanitary Corps. Although he was granted the use of a separate tent, which stood side by side with those occupied by the Native Sanitary Corps natives, he, however, spent the whole of his leisure time with these natives and associated intimately with them. The natives of this corps had been recruited but three months previously, direct from their homes and had come in perfect health. It is a noteworthy fact that the head native of this gang occupied, with his family of six, a tent a sho:t distance apart from the other natives and although their diet was similar to that of the corps none of them were affected with scurvy. The greater cleanliness of this head native's tent, as compared with the others, was also striking.

The marked contrast in the prevalence of scurvy in these two units-namely, 76 per cent. in the scavengers and 16 per cent. in the porters-under precisely the same dietary, again points to a factor other than food as the prime cause of the disease. Nor can that factor be entirely the unwholesomeness of the work of the Native Sanitary Corps because other diseases due to insanitary conditions, such as diarrhœa, were markedly absent. It may be further mentioned that although these two units, the scavengers and the porters, occupied separate quarters within a few hundred jards of one another, they were practically on one inclosed piece of land.

Next with regard to the mule-drivers. Their food was exactly the same as that of the ordinary European soldiers with the exception of the lime juice ration. The cavalry, artillery, and pom-pom section natives lived in tents in the same camps as the European cavalry and artillery. Their surroundings were therefore comparatively cleanly and the incidence of scurvy varied from total absence in the pom-pom section to 22 per cent. in the cavalry natives. On the other hand, the natives of the Army Service Corps, who lived in a large encampment by themselves and whose tents were uncleanly and compared unfavourably with those of the cavalry and artillery natives, had 32 per cent. affected. Of the 400 men examined belonging to this division 200 were leaving for their homes on the following day, their contract period of service having expired. They complained of feeling too ill to work and refused to sign afresh any contracts for further employment. Quite one-half of this number were suffering from scurvy. It will be said, however, that the regular troops were supplied with lime-juice but not the natives. It may be pointed out, in return, that lime-juice was offered to all military natives in December, 1902, and the prevalence of scurvy was greatest in 1903 . It must further be stated that the lime-juice was left severely alone by nine out of every ten men, troops and natives alike. This raw lime-juice was too acrid, too raw, and gave severe colic to many. It could not possibly be drunk without sugar and sugar was too valuable for other purposes to be taken to improve extremely unpalatable lime-juice. The ultimate result was that the natives attached to these corps and living with them had precisely the same dieting as the English troops. Still only the natives were found affected by scurvy and that corps of natives (the Army Service Corps) was most affected whose camp was most unclean and least under direct military supervision.

Here, again, proof seems to be wanting that the food factor is the cause of scurry. In this connexion, further, the condition of affairs in the 19th Hussars is interesting. One squadron of the 670 Europeans forming the regiment were buying fresh vegetables regularly in addition to their ordinary rations. The remaining two squadrons subsisted on the rations issued; there was no sign of scurvy in either section.

4. African natives attached to the civitian Repatriation Department.-The last unit in which inquiry was made as to the incidence of scurvy comprised 900 natives of Africa employed as drivers and leaders of mules by the Repatriation Department-a civilian organisation inaugurated on the cessation of hostilties. The sick of this corps were treated at the hospital in the burgher camp, Standerton, when too ill to look after themselves; but when merely unable to work were kept in sick detention tents close by their regular quarters. Between August, 1902, and February, 1903, the department being in full working order, 80 cases of all diseases were admitted to the hospital. Of these 50 -i.e., 62 per cent. -were cases of scurvy. In February, 1903, a final $B$ B 2 
inspection of the natives of this department was made. Of the 900 employed 500 were examined and 252 were found to be affected-i.e., 50 per cent. Of the 14 cases in hospital 12 were scurvy; of the 14 in the sick detention tents 12 were scurvy. In connexion with this inspection the diagncsis of the cases was confirmed by the senior medical officer of the burgher camp, Standerton (Dr. Alexander).

Again, the feature to be noted is that the food of these natives was quite as plentiful (in some respects more so) as that supplied to the natives under military control ; but, on the other hand, their camp was the least tidy and cleanly of all at Standerton. The tents were overcrowded, closely packed together, and arranged with a total disregard for sanitation. The area of this camp, containing 900 men, was only one-third in exten's of that occupied by the Scottish Kifles who numbered 500. The statistios of the sick in detention tents were not kept or the tale would have appeared heavier. Although the natives of the Repatriation Department did not outnumber by any means the natives in military employ the incidence of scurvy amongst them was the heaviest of all native units at Standerton. A consideration of this fact, then, that this body of natives with the best and most liberal food-supply in the town had the heariest incidence of scurvy again points to the conclusion that food as a factor in the production of the disease must be eliminated.

Further evidence against food being the prime cause of the condition is afforded by clinical study of the casesmore especially by consideration of the mode of onset and the results of treatment. All these cases of scurvy com menced as an inflammation of the gums and the general symptoms followed at varying intervals but always secondarily to the gum condition. Improvement or the reverse followed pari passu with improvement or aggravation of the gum condition. This inflammation of the gums occurred in all cases without exception and in a definite manner. The process was as follows. Around the tooth and next to the gum was first noticed a collection of food. The gum edge nearest this aggregation soon became of a deeper red tint. This deeper tint area spread rapidly, but in the early stage was always separated from the healthy gum by a definite violet-maure demarcation line. In a few days the whole of the gums, both internally and externally, became involved in the inflammatory process and areas devoid of teeth which had hitherto been healthy were now affected. At this stage the affected tissues were deep red in colour, soft, swollen, and compressible, tender, and bled easily on pressure. In a day or so the gams became easily separable from the teeth, and deep down, between the gams and the teeth, definite masses of a cream-cheesy consistency and colour could be seen and removed. These masses on micro scopic examination were found to consist of pus cells, namerous micro organisms of various kinds, and food débris. At this stage there were no constitutional symptoms nor could any changes be detected in the cardio-vascular system. These conditions developed later at varying intervals and it was found that they did not develop when means were adopted to improve the gum condition. Moreover, in cases in which the general disturbance was present there could be no ultimate recovery without a prior return of the gum condition to the normal. The method of treatment adopted, therefore, consisted of rest in the open air, isolation from previous surroundings, coupled with rigorous and frequent mouth antisepsis, care being taken to remove the cheesy masses mentioned above. The rate of general improvement and return of the gums to the normal condition was in direct proportion to the amount and efficiency of the antiseptic treatment employed for the mouth.

The fact that these cases when seen early could be completely cured by this treatment alone-with, be it noted no alteration of any sort in the diet-argnes directly against the diet being the prime cause of the condition. Further, the value of local treatment for the mouth condition is emphasised by a comparison of the results of treatment in advanced cases by (1) local plus constitutional treatment and (2) by constitutional treatment alone. For local plus constitutional treatment the average length of residence in hospital was from 20 to 30 days, but for constitutional treat. ment alone it was from 60 to 90 days. It is also interesting to note that in advanced cases in which mouth antisepsis was employed there was little or no pyrexia, but that periods of pyrexia were a feature of similar cases in which this treat ment was omitted.
These clinical facts, therefore, seem to suggest that the condition is not due to the food but is one caused by an infection through the gums and mouth. Whether the system is infected directly through the gums or through the swallowed saliva after the gum condition has developed cannot readily be determined.

Further, that the condition was found to prevail only among natives concentrated at Standerton, and then only in direct proportion to the absence of discipline and Earopean habits of cleanliness, points to the fact that the unchecked habits of natives must in some measure either account for, or at least increase, the liability to the disease. The natives seldom used soap and rarely did they wash their hands or faces, and a large proportion, though they wore little or no clothing, were extremely verminous. This clothing was second-hand and usually consisted of one or more cast-off European garments which were very filthy and but seldom washed. They rarely washed their blankets and never swept out their tents. They had common eating and drinking utensils and frequently several ate out of one dish at the same time. Though dental caries is less common among them than among Earopeans they rarely washed out their mouths. The majority of the natives chewed tobacco, "black cavendish" being easily obtainable through the troops, and not infrequently they passed the halfchewed "quids" from one to the other for tarther use. With this chewing there was expectoration free and plentifula habit found impossible to repress. Then they used mouth-organs and similar instruments in profusion, passing them from one to the other. They left both half.eaten food and food in preparation lying about on the ground inside and outside their tents. Moreover, the tents were always in use and crowded during their off-duty time. Altogether these habits formed an excellent basis for the conveyance of any mouth-to.mouth infection.

To sum up-

1. The outbreak at the burgher camp, Middelberg, among Europeans and natives, was attributed to the nature of the food supplied. It was noticeable that the European sufferers consisted mainly of those persons who from advancing years were unable to fend for themselves, and of those who, suffering from mental depression at the prolonged separation from relatives, neglected to obey even the ordinary rules of personal cleanliness. Moreover, the cause could not have been in the food, seeing that food of precisely similar nature was in use at Standerton and Volkrust, and yet scurvy was entirely absent from these latter camps. But, on the otber hand, the sanitary condition of the Middelberg camp was much inferior to that of the other camps named. At this time a determined effort was made to improve the sanitary condition of camps. Soap and fuel were ordered to be issued in unlimited quantities, whereas previously they had been supplied in restricted amounts. These articles were included in a new ration scale which was also introduced at this time. Scurvy now disappeared from Middelberg. It may be said that the cessation of the disease was due to the new diet provided, but the total absence of scurvy under the old dietary scale at Standerton and Volkrust is entirely opposed to this view, and it is remarkable that the disappearance of the disease was as markedly coincident with improved personal cleanliness in the Middelberg camp as with the change in diet.

2. Scurvy did not appear in the district of Standerton until the last month of the war when the mobile troops became stationary and concentrated into large units in the immediate neighbourhocd of the town. Further, it continued with increasing severity among these units when war had ceased and when restrictions in the way of purchasing extra food had been withdrawn. After the war all classes were free to supplement their Government rations by purchasing fruit and vegetables at the various provision stores in the town. Special inquiry was made among those showing well-marked signs of the disease as to whether or no fresh fruit or fresh vegetables had formed part of their dietary in addition to the official supply of rations. In many cases there was abundant satisfactory evidence forthcoming to the effect that the sufferers were purchasing and consuming fresh pineapples, fresh bananas or fresh melons, and other vegetables imported direct from Natal. It is highly probable that these natives, whose daily pay always equalled and in many cases exceeded that of the English soldier, both purchased and consumed regularly a larger quantity of fresh vegetables or fruit than was the custom of cưr British Firopean troops, 
3. The only European affected at Standerton was attached to the Native Sanitary Corps-a unit of which 76 per cent. suffered from scurvy. Let it be noted, however, that this European lived with these natives. His diet was similar to that of the other Furopean soldiers at Standerton, but he spent the whole of his time in the company of these scavengers and by reason of this mode of life was freely exposed to any mouth-to-mouth infection. On the other hand, the family of the head native, consisting of six individuals, was unaffected by scurvy. Their dietary was that of the Native Sanitary Corps, but they lived in a tent at a short distance from the scavengers' encampment and their standard of personal cleanliness was of a high order.

The varying incidence in the two units - the Native Labour Corps and the Native Sanitary Corps-namely, 16 per cent. in the former and 76 per cent. in the latter-cannot be ex. plained by the food alone, since both units were on precisely the same diet.

4. With regard to the other natives inspected at Standerton not one of the 150 employed at the burgher camp as servants to the European camp staff was found to be affected, nor did natives employed as domestic servants in the European military messes, shops, or households in the town show signs of the disease ; but in the remaining units, both civil and military, scurvy prevailed directly as the filthy habits of the natives were allowed to go unchecked by direct European control.

5. Of those sufferers from scurvy admitted to the military hospital at Standerton 12 per cent. died. Of those who recovered 90 per cent. returned to their former daties, their former dietaries, and their former surroundings ; and though they lived among men afflicted with scurvy, yet the hospital records do not furnish a single instance of a patient once recovered from scurvy seeking readmission for a recurrence of the disease.

These facts, therefore, concerning the incidence of scurvy in the various bodies of individuals seem to be against the contention that food is the sole cause of the disease; and, moreover, the clinical facts also would seem to oppose the contention. The infection appears to occur through the mouth, the general system being involved later and secondarily. The manner in which the primary infection occurs and how it gives rise to the manifestations of the disease in the mouth are points on which it is not easy to make any definite statement and further investigation is required.

In conclusion, I submit that the facts adduced seem to prove that scurvy is not due to either the presence or absence of any particular kind of food from the dietary but rather to an infection for which food may act as a vehicle under conditions of dirty storage or dirty preparation; and considering that the disease prevailed in inverse proportion to the standard of personal hygiene of the individuals affected its infectivity would seem to depend on the insanitary habits and perhaps the unwholesome occupation of those who were its victims.

WeEkly Dietary SoAles AND INCIDENCE OF SCURVY.

A. - In use at all Burgher Camps till Dec. 31st, 1901.

Adults.-Flour, $7 \mathrm{lb}$; sugar, $12 \mathrm{oz}$. ; ground coffee, $6 \mathrm{oz}$; ; salt, $4 \mathrm{oz}$. ; tinned meat, $2 \mathrm{lb}$

Children (6-12 years).-Flour, $71 \mathrm{~b}$; sugar, $12 \mathrm{oz}$; ground coffee, $3 \mathrm{oz}$. ; alt, $2 \mathrm{oz}$; t tinned meat, $1 \mathrm{lb}$.

Children (1-6 years).-Flour, $3 \frac{1}{2}$ lb. Remainder, as children (6-12 years)

Note.-When fresh meat served out-adults, $3 \mathrm{lb}$; children, $2 \mathrm{lb}$. Tinned milk issued, " made up" by dispensers with water, ready for drinking, for children only, and issued daily but for adults only on medical officer's order. Wood and coal issued when required.

B.-Introduced to all Burgher Camps Jan. 1st, 1902.

\begin{tabular}{|c|c|c|c|c|c|c|c|c|c|c|}
\hline Age. & 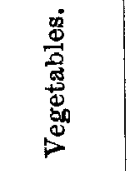 & $\stackrel{\dot{\vec{g}}}{\stackrel{\vec{g}}{\mathbf{s}_{1}}}$ & 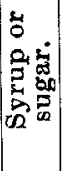 & 递 & 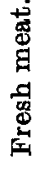 & $\begin{array}{c}\frac{ \pm}{a} \\
\tilde{D} \\
\tilde{D} \\
.\end{array}$ & 蒫 & 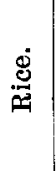 & $\begin{array}{l}\dot{2} \\
\stackrel{8}{8} \\
\text { in }\end{array}$ & 离 \\
\hline & lb. & lb. & oz. & oz. & lb. & oz. & & lb. & lb. & oz. \\
\hline Adults $\quad \ldots \quad \ldots$ & $1 \frac{1}{2}$ & 7 & 12 & 7 & 4 & 4 & 1 tin & 1 & $\frac{1}{2}$ & 4 \\
\hline $\begin{array}{c}\text { Children, } \\
\text { years }\end{array}$ & $1 \frac{1}{2}$ & 5 & 12 & 4 & 3 & 4 & 7 qts. $^{*}$ & $\frac{\mathrm{I}}{2}$ & $\frac{1}{2}$ & 4 \\
\hline 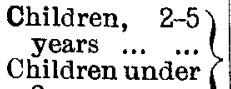 & $\begin{array}{l}\text { As sup- } \\
\text { plied by } \\
\text { camp }\end{array}$ & $3_{2}^{\prime}$ & 12 & - & 2 & 2 & 14 qts. $^{*}$ & $\frac{1}{2}$ & $\frac{1}{2}$ & 4 \\
\hline 2 years... $\ldots)$ & matr & $2 \frac{1}{2}$ & 12 & - & - & 2 & 14 qts.* & -- & $\frac{1}{2}$ & 4 \\
\hline
\end{tabular}

* Tinned milk, made up by dispensers with water, daily ready for consumption.
$\mathbf{A}+\mathbf{B}$ - Incidenoe of Sourvy.

Camp populations-children, 48 per cent.; adults-male, 12 per cent. female, 40 per cent

Burgher camp, Volkrust, population, 5000, nil; burgher camp, Standerton, population 5000 , nil; burgher camp, Middelberg, populaion, 6000 Europeans, 100 cases.

Outbreak in December, 1901, and January, 1902.

\section{C.-Eurnpean Soldiers-at Various Times.}

Bacon or cheese, jam, frozen meat, fresh meat, tinned vegetables and meat, coffee, sugar, salt, rum, soap and fuel, tea, lime-juice (not usually taken).

Admissions to No, 17 General Hospital, Standerton, 22,000. Seurvy, nil.

Examined on duty, 3000. Scurvy, one. (This man was in charge of transport section of Native Sanitary Corps, F.I. 2.)

D.-For Natives employed in Burgher Camps : Standerton, Middelberg, and Volkrust.

Flour, $7 \mathrm{lb}$; ; sugar, $8 \mathrm{oz}$. ; coffee, $4 \mathrm{oz}$; ; salt, 4 oz. ; meat, $1 \mathrm{lb}$.

Total employed at each camp, 150.

Scurvy at Middelberg, one case; scurvy at Standerton and Volkrust,

\section{E.-For Natives employed by Military as Muleteers.}

Lime-juice issued in December, 1902, but not taken.

Bread, flour, or biscuits, $7 \mathrm{lb}$; sugar, $14 \mathrm{oz}$; coffee, $3 \mathrm{oz}$; meat

$7 \mathrm{lb}$; ; salt, $2 \mathrm{oz}$.; tinned vegetables bi-weekly, as for Kuropean troops.

Attached-lst' Essex, Rifle Brigade, Leicesters. 60 examined (July, 1902) outside Standerton. Scurvy, nil.

Attached-Army Service Corps Transport at Standerton, 1903.

Officers' Cape Cart line, 9 men. Seurvy, nil.

Police ... $\ldots$... $\ldots .8 \mathrm{men}$. Scurvy, 4.

Muleteers, 400 examined. Scurvy, 32 per cent.

Attached-Pom pom Section, 9 men. Scurvy, nil.

Attached-19th Hussars and 83rd Field Battery R.A., 67 men. Scurvy, 22 per cent., at Standerton, 1903.

\section{F.-For Labourers employed by Military as Porters and Scavengers.}

Mealie meal, $16 \mathrm{lb}$; meat, fresh, $1 \mathrm{lb}$; lime-juice, 1 oz, weekly in December, 1902, but not taken.

Excess mealie meal (this was burnt and drunk as a black liquor termed " native coffee"), fermented makes a drink called "mahow" (intoxicating)

I. Native Sanitary Corps (Scavengers). February, 1903, at Standerton.

1. Examined, 34. Scurvy, 76 per cent.

2. Transport, 7. (To the transport section is attached the European under Dietary C who was affected with scurvy.) Scurvy, 100 per cent. 3. Later examined, 20. Scurvy, 100 per cent.

4. Head native with family of six, living separate. Scurvy, nil.

II. Native Labour Corps (Porters).

Employed, 120. Scurvy, 16 per cent. Examined, February, 1903, at Standerton.

G.-Natives employed by Repatriation Department, Standerton, as Muleteers.

Bisouits, flour, or meal, $7 \mathrm{lb}$; meat, chiefly fresh, $7 \mathrm{lb}$; coffee, $7 \mathrm{oz}$; salt, $3 \frac{1}{2} \mathrm{oz}$; lime-juice, 1 oz.; sugar, $2 \mathrm{l}$ oz. ; wood, $14 \mathrm{lb}$.

Employed, 900 ; examined, 500 ; scurvy, 50 per cent.

In hospital, 14 ; scurvy, $12=86$ per cent.

In detention tents, $14 ;$ scurvy, $\frac{12}{12}=86$ per cent.

Canterbury.

\section{THE TREATMENT OF TABES DORSALIS AND ITS PROGNOSIS.}

\section{BY DR. MAURICE FAURE.}

IT is an erroneous idea to consider tabes as a disease amenable to one method of treatment, that is to say, by drugs. Whether the drug be nitrate of silver, which was formerly employed, or mercury, which is employed nowadays, the idea remains the same and the object is to care the patient by means of a drug. A nervous disease is not an equation in which the observer may set one poison as equally opposable to another poison. The evolution of tabes bears a definite relation to various infections and intoxications. The patient is always a complex problem and the physician must in every case take into consideration such causes as syphilis, overwork, alcoholism, tobacco poisoning, influenza, tuberculosis, and the like. On account of the predominant part played by syphilis in the pathogeny of tabes it is indisputable that antisyphilitic treatment ought always to be tried, at all events at the beginning of the attack, and especially if the tabetic patient have not previously undergone antisyphilitic treatment, but this treatment should not be kept up as a routine and particularly when it is observed to give bad results. Certain cases of syphilitic tabes which are vigorously treated with mercurials given in increasing doses from the beginning of their rapid evolution are often much improved and furnish the greater part of the cares 